\title{
Mida inimene tõeliselt vajab? Tüpoloogiline määratlus
}

\author{
Mario Rosentau \\ Õigusteaduskond, Tartu Ülikool
}

\begin{abstract}
Inimvajadus seletatavana on empiirilis-teoreetiline mõiste, mille kaudu on sõnastatavad mitmed humanoloogilised normtasemeseadused. Vajadus seletajana on teatavate otsuste õigustaja. Artiklis visandatakse vajaduse teoreetiline mudel, mis kirjeldaks kindlat hulka praktiliselt paratamatuid inimelu fenomene, mida nimetatakse vajadusteks, seletaks vajaduste ilmnemist ja õigustaks vajaduste rahuldamisele ehk kahju vältimisele suunatud tegevust. Mudeli tarvilikud tingimused on vajaduse subjekt — inimisik või inimgrupp; vajaduse objekt ehk otstarve, mis rahuldab vajaduse ja kõrvaldab vajaduspinge; potentsiaalne kahju, mis vältimatult sünnib vajadushüve puudusest; vajaduse vältimatuse tingimused - kindlad sõltuvusseosed inimkeha ja inimvaimu ning materiaalse ja kultuurilise elukeskkonna vahel; vajaduse pingetegur - sõltuvusseostest tulenev sund tegutseda vajaduse rahuldamise sihil. Inimvajadused on liigitatavad kahte kategooriasse ja mitmesse tüüpi. Vahetud vajadused on organismi füsioloogilised ja psüühilised vajadused ning organismi ja isiksuse keskkonna- ja elutingimusvajadused. Vahendlikud ehk funktsionaalsed olukorrakohased vajadused on tarbed vahendite järele, vältimaks või vähendamaks tõsist sattumuslikku kahju (nt kirurgia, ravimid); tarbed vahendite järele, rahuldamaks vahetuid vajadusi (nt toiduainete tööstus); tarbed vahetuid vajadusi rahuldava koostöö ja ressursiallikate järele; lõpuks tarbed innovaatiliste vahendite järele, millega tagada normtasemele vastavat eluviisi (nt elatusraha, osasaamist kultuuripärandist). Sellisena väljendab vajadus teatavat elutähtsat tingimust, mille kestev puudus tekitab vältimatult inimisikule tõsist kahju ja mille potentsiaalne või lühiajaline puudus avaldab inimesele praktiliselt paratamatut motiveerivat survet. Mis tahes vajaduse rahuldamise tõeliseks aluseks on isiksuse tõsise kahjustumise vältimine.
\end{abstract}

Märksõnad: inimloomus, inimtegevus, inimese vajadused, vajaduste rahuldamine, eluviis, normaalsed elutingimused, humanoloogilised normtasemeseadused

Autori aadress: Mario Rosentau, Õigusteaduskond, Tartu Ülikool, Näituse 20, 50409 Tartu. E-post: mario.rosentau@ut.ee.

An abstract in English is available at the end of the article. 


\section{Vajaduse mõistest}

Kujutlegem tänapäeva linna tüüpilist elanikku, kes vajab kindlaid asju selleks, et elus püsida: süüa ja juua, riideid ja toasooja; tänaval liiklemise oskusi; häda hetkel tuletõrjet, kiirabi või politseid. Teatud asju vajab ta selleks, et teha tööd, olla rahul ja armastada. Et olla õnnelik. Peale selle arvavad inimesed vajavat palju muudki, mille vajalikkuses kaugeltki kõik ei ole ühte meelt. Inimestel on huvid, soovid ja ihad, mis on suunatud teatavatele asjadele. Mõned asjad on vältimatud selleks, et mitte kannatada, teised selleks, et nautida tavalisest enamat. Üks on kindel: vajadustest kõneldakse. Kusjuures 'vajaduse' või 'vajama' kasutus ei ole vajadustest kõnelemiseks tarvilik. Vajadustele näivad osutavat ka 'joogivesi peab olema puhas', 'tulekahju tuleb kustutada' jne.

Vajaduse mõiste kohta võime mõttekalt küsida järgmist. (1) Kas vajadus on loomulik liik? (2) Kas vajadus on teadusteoreetiline mõiste? (3) Kas vajadus on teaduskeelest elimineeritav või evib see mõiste taandamatut teoreetilist funktsiooni?

Lugedes bioloogilised tarbed "loomulikeks", võime öelda, et vähemalt osa vajadusi on loomulikud asjad. Teooria loomulikest vajadustest saab olla teaduslik või kõnekeelne. Kõnekeelne "loomulik vajadus" on kõnes olemas. Samas on ilmne, et kultuur- ja heaoluühiskonna inimene ei rahuldu "loomulike vajadustega". Teisalt, moodne eluviis pakub hulga hüvesid, mida on raske lugeda vajadusteks kasvõi selle tõttu, et need on kättesaadavad vaid vähestele. Järelikult peab vajaduste teooria käsitama lisaks bioloogilistele ka mittebioloogilisi tarbeid, samas välistama viimaste hulgast "ülemäärased soovid" ja luksushüved.

Kui on nii, et me argikõnes ei suuda järjekindlalt ja ühetaoliselt osutada "asjadele" nimega 'vajadus', ent samas ei saa me tõsistel kaalutlustel nendest kõnelemisest ka loobuda, siis saab vajadus eksisteerida üksnes mingi "vajaduseteooria" entiteedina. "Vajaduseteooria" võib olla kõnekeelne või teaduslik. Kõnekeelne teooria tähendab, et leidub hulk lausungeid ja kõnelemise viise, mis kasutavad vajaduse terminit ning osutavad 'vajadusteks' nimetatavatele nähtustele. Teaduslik vajaduseteooria võib esineda kahel kujul ja viisil. Esiteks, teooriana vajadustest: teooria määratleb vajaduse mõiste ja omistab vajaduse terminile sihipärase teoreetilise otstarbe. See on 'vajaduse' teoreetiline eksplikatsioon. Teiseks, "varjatud" vajaduseteooriana mõne muu teooria koosseisus: teooria uurimisobjekt on midagi muud kui vajadused, ent teatavate seoste tõttu kasutatakse teoorias ühel või teisel viisil vajaduse mõistet ja termineid. Siis on võimalik 'vajaduse' teoreetiline implikatsioon. 'Vajaduse' argi- ja teoreetilise kasutuse vahevarianti, nt poliitilises argumentatsioonis, võime nimetada praktiliseks kasutuseks.

Vajaduse teaduslik mõiste oleks seletatav üldiselt ja seletaja konkreetselt: 
mis on inimese vajadus? Ja mida inimene tõeliselt vajab? Samuti oleks see otsuseid õigustav: miks tuleb vajaduste rahuldamise nimel pingutada? Küsimus on niisiis selles, kas ja millisena teoreetiline vajadus on mõttekas?

\section{Probleem}

Tõik, et vajaduseteooriaid on esitatud, ei tingi, et vajaduse mõiste on taandumatult mõttekas. Õhu, vee, toidu ja mõne muu asja tarve on vältimatu, et üldse millestki rääkida oleks. Kuid neist asjadest tingimata ei piisa inimese õnneks. Õnne tegurid erinevad paraku isiksuseti ja kultuuriti. Siit määratlemise esimene raskus. Teiseks, kui organismi tarbed on inimestel olemas sõltumata sellest, kas nad elavad linnas, maal või Kuul, siis lisaks neile esineb hulk tarbeid, mis on tingitud nimelt sellest, kus ja kellega nad koos elavadtöötavad.

Seniste käsitluste puudused võib kokku võtta järgmiselt.

1) Need esitavad vajaduste kontseptsiooni üksikute tunnuste - tavaliselt objekti, pinge või rahuldamata vajadusest tekkiva kahju — kaudu, loomata vajaduse teoreetilist mõistet, mis eviks küllalt selget ja täielikku sisu (tunnuseid) ning adekvaatset mahtu (osutust).

2) Rääkides vajaduste objektidest või üksikutest tunnustest, need teooriad pigem loetlevad vajadusi ja nende allikaid ning osutavad nende oletatavale hulgale, kuid ei kasuta vajaduse fenomenide seletamiseks täpset ja hõlmavat üldmõistet.

3) Teooriad seletavad hästi esmaseid, füsioloogilisi ja orgaanilisi vajadusi, kuid ei seleta hästi teiseseid, eluviisilisi vajadusi. Tulemuseks on valik kahe halva vahel: teiseseid vajadusi kaasates saab uurimisobjekt hägustatud, neid eirates saab see aga taandatud piirini, kus uurimisobjekt minetab seletusjõu.

Vajaduseteooria põhiküsimuseks on "demarkatsiooniprobleem": kuidas tõelisi vajadusi eristada vajadustele sarnastest fenomenidest nii, et vajaduste hulk ei piirduks üksnes n-ö ellujäämisvajadustega, vaid arvestaks ka isiksuse vaimsete, hingeliste, ühiskondlike jt huvidega, ja teistpidi - et käsitlus ei tingiks kvaasi- ja pseudovajaduste haaramist seletusmudelisse.

Tuntuim vajaduste käsitlus on A. Maslowi motivatsiooniteooria (Maslow 1987). Mõnede arvates Maslow siiski vaid nimetab vajadusi, tegelikult rääkides inimtegevuse ajenditest (impulssidest). Motivatsiooniteooria osutab vajadustele üksnes siis, kui impulsi tekitaja ja vajaduse objekt kokku langevad. Paraku on lihtne näidata, et paljudel juhtudel ei ole ajend ja vajadus samased (Thomson 1987, 14-15). Lisaks sellele ei rajane Maslowi "vajaduste 
hierarhia" vajaduse teoreetilisele mõistele, pigem on tegemist üldistatud empiirilise loendiga. See ei esita vajaduste selget tüpoloogiat. ${ }^{1}$ Neil kaalutlusil jätame Maslowi käsitluse siin tähelepanuta.

Garrett Thomsoni Vajadused (Thomson 1987) ning Len Doyal'i ja Ian Gough'i Inimvajaduse teooria (Doyal ja Gough 1991) on vajaduste uuematest käsitlustest ühed põhjalikumad. Esimene teos järgib analüütilise filosoofia tavasid ja rakendab selle meetodeid, empiiriasse eriti süüvimata. Teine teos aga, vastupidi, kasutab varasemate analüüside tulemusi empiiriliste üldistuste ja liigituste tegemiseks, tuvastamaks olulisi seoseid ühelt poolt inimeste heaolu ja seda ähvardavate ohtude ning teiselt poolt sotsiaal-, majandus- ja kultuurpoliitiliste kalduvuste ja meetmete vahel.

G. Thomson lähtub vajaduse tähendusanalüüsis kahju mõistest. Analüüsi tähtsaim tulemus on inimlike vajaduste tõsiasjalise objektiivsuse ja elulise tõsiduse sedastamine. Vajaduste tõsidus seisneb praktilises paratamatuses hoiduda potentsiaalsest tõsisest kahjust (sellest allpool). Paraku läheb Thomson vajaduse mõiste teoreetilise lihtsustamise ja taandamisega liiga kaugele. Selle tulemusel näeb ta inimvajadusi ajas ja ruumis peaaegu muutumatutena ja ühiseluviisidest puutumatutena. Lõpuks jääb tema käsitlusse mitu tõsist lünka, mis lõppkokkuvõttes ähvardavad kummutavate järeldustega kogu teooriat.

Varasemaid uurimusi arvestades pühendab Thomson palju kriitilist tähelepanu soovi rollile teoaluste ${ }^{2}$ seletamisel ja tegude põhjendamisel. Ta esitab probleemi: kuidas eristada tõelisi ehk vältimatuid vajadusi pelkadest soovidest (luksus)hüvede järele? Thomson näitab arutluses veenvalt ja kahtlusi jätmata, et vajadused ja soovid pole samased. Kuid keskendudes vajaduse mõiste puhastamisele soovi tunnustest, teeb Thomson esimese olulise vea: ühes sooviga heidab ta tegevuse (sh vajadustest ajendatud tegevuse) aluste hulgast minema mis tahes teadliku teo lähima aluse - kavatsuse. Thomsoni teine viga seisneb inimese ühiselulise olemuse ajaloolise arengumõõtme eiramises: inimese eluviisi mitmekesistumises ja inimkultuuri arenedes muutuvad otsustavalt ka need elutingimused, milliste mittetäitmisel saaksid isikud kahjustatud. Kahju vältimine aga, nagu saame näha, on vajaduse rahuldamise tarvilik ja küllaldane tingimus. Seepärast, kui sotsiaalse ja kultuurse inimese arengut mööda muutuvad inimväärse elu tarvilikud tingimused, muutub (paratamatult) ka nende tingimustega seotud kahju mõiste.

Vajaduste formaalloogiliselt korrektne liigitus näib eelmainitud raskuste tõttu juba ette välistatud olevat.

2 Inglise keeles 'reason'. Lähtun D. Davidsoni teesi, et teoalus on teo põhjus, kui inimene sooritab teo just selle teoaluse tõttu, täpsustusest: teadliku teo lähim põhjus on kavatsus, mis ei tarvitse hõlmata kogu teoalust (ka tahtevastaselt käsu järgi tehtud teod eeldavad kavatsust, ent käsk ei ole teo lähim põhjus). 
Puudustele vaatamata annab Thomsoni analüüs hea lähtealuse vajaduse mõiste edasisele analüüsile ning tulemuste sünteesivale tõlgendamisele, mis süvendavad vajaduse fenomeni kui inimtegevuse põhilise survestaja ja motivaatori mõistmist.

Esitan hüpoteesi, et vajadus seletatavana on empiiriliselt kinnitatav teoreetiline mõiste, ligikaudu nagu jõud füüsikas, mille kaudu on sõnastatavad mitmed n-ö humanoloogilised normtasemeseadused. Vajadus seletajana oleks aga "kasulik mudel". Käesoleva artikli sihiks on visandada teoreetiline mudel, mis: (1) võimalikult täpselt ja täielikult kirjeldaks võimalikult suurt hulka fenomene, mida me kindlate tunnuste alusel nimetame inimvajadusteks; (2) hüpoteetiliste evolveeruvate normtasemeseaduste alusel seletaks samade fenomenide ilmnemist; (3) vajaduse mõiste sobiva eksplikatsiooni kaudu õigustaks vajaduste rahuldamisele (ehk kahju vältimisele) suunatud tegevust. Vajaduste mudel oleks seega printsipiaalselt lihtne, seletav ja õigustav.

\section{Inimese loomusest - tegutseda õigesti}

Inimloomuse kohta on raske midagi uut öelda. Ent öeldut tasub kohandada käesoleva arutluse mõistestikuga. Sest inimloomuse mõiste annab aluse kahju mõiste määratlusele ja sellega vajaduste tüpoloogiale.

Inimloomust võib mõista kolmes tähenduses:

a) hõlmavas: inimese mis tahes omadus on osa tema loomusest;

b) vastanduvas: inimesel on loomulikud (algsed) ja mitteloomulikud (omandatud või omistatud) omadused;

c) domineerivas: isiksuse loomus seisneb tema valitsevates joontes.

Inimloomuse hõlmav kirjeldus ei ole vastuvõetav, sest ei erista looduslikke (bioloogilisi) omadusi mitte-looduslikest (sotsiaal-kultuurilistest jt). Ka vastandav kirjeldus ei ole vastuvõetav. Sest ehkki mõistus, keel, moraal, ühiskond, loovus jm omadused on teiste bioloogiliste liikidega võrreldes eriomadused, on nende teke saanud (tõenäoliselt) võimalikuks tänu inimliigi bioloogiliste tunnuste mutatsioonidele. Kõige tõepärasemalt on inimloomus kirjeldatav teatavate dominantsete joontena (Thomson 1987, 31-34).

Inimene teeb tegusid, mida teised organismid ei tee. Sestap on mõttekas lähtuda kirjeldusest, mis esitab loomuomadusi tegevust väljendavate kesksõnaliste "muutlike" predikaatidena, mitte tavapäraste omadussõnaliste "püsivate" predikaatidena. Niiviisi saame mõneti moonutatud staatilise pildi asemele tõepärasema dünaamilise pildi. Näiteks, püsikirjeldus 'inimene on sõbralik olend' näib mõneti mittevastav, sest pea ükski inimene pole sõbralik 
alati ja kõigi vastu. Tegevuskirjeldus 'inimene on sõbrustav olend' on kohasem, sest kui inimene vahetevahel ei sõbrustagi — naudib üksindust või on pahas tujus -, siis vastutõik ei kummuta väidet sõbrustavast inimesest seni, kuni enamik inimesi aegajalt sõbrustab. Tegevuse korrektne tüpoloogia peaks muuhulgas näitama, millised organismi elulemiseks vältimatud teod on teisenenud tegudeks, mis on vältimatud isiksuse eluväärtustena. Lõpuks, lähtumine inimtegevusest muudab inimloomuse määratluse "positiivseks": osutades reaalsele (aktuaalsele ja potentsiaalsele) tegevusele, välistab määratlus pelgalt mõeldavad, "müütilised" omadused, mida mõned õpetused on üritanud inimloomusele omistada.

Mõistagi ei tarvitse inimese tegevuspotentsiaali kirjeldamine olla küllaldane inimloomuse määratlemiseks. Kuid see võib olla piisav isiksuse kahjustumise teatavate varjatud kriteeriumide määramiseks. Kui keegi oma õigusvastase tegevusega isiksust kahjustab, on asi põhimõtteliselt selge ning sellega tegeleb riiklik õiguskaitse. Kuid sageli saab isiksus kahjustatud selle tõttu, et ta ei saa teha teatavaid tegusid, mida ta eelnevat elukäiku ja ühiskonna elustandardeid arvestades peaks saama teha. Näiteks, kui inimene on omandanud elukutse, aga ei saa vastavat tööd, siis kannatab ta kahju, sest on hariduse omandamiseks kulutanud elamise aega ja samas ei saa õpitud oskusi kasutada oma heaoluks. Inimlikel põhitegevustel on teatavad vältimatud eeldused ja hulk eluliselt olulisi tulemusi. Eeldusteks on tüüpilised isikuomadused: huvid, võimed, teadmised, oskused jne. ${ }^{3}$ Näiteks, põlluharimise oskused erinevad otsustavalt organismi liigiomastest toitumise oskustest, ehkki mõlema üldiseks eelduseks on võime teha kehalist tööd. Ent kui "metsik organism" rahuldub täis kõhuga, siis põlluharija mitte. Sest tegusad inimesed omistavad üksteistele - lisaks tegevuse "loomulikele" omadustele - tuletatud või rajatud väärtusomadusi: inimeseks-olemise ja hea elu tunnuseid ja tingimusi ("aus, töökas ja jõukas talupoeg"). Mõned tegevused on inimlikeks väärtusteks iseenesest (põllutöö kui elutöö), teised on sihitud väärtuste loomisele (põllutöö kui toidu allikas). Järelikult, kui inimese võimed, huvid, teadmised, oskused on õpitavad ja arendatavad ning inimväärikus rajatav, siis inimloomus muutub. Seda nii isiklik-eluloolises kui ka ühiskondlik-ajaloolises perspektiivis.

Niisiis, tegutsev inimene (1) on isetoimiv (toituv, liikuv, paljunev, tunnetav...) elav organism, kellel on tervis ehk liigiomane ja individuaalne kehaline ja psüühiline valmisolek kasvada ja óppida (2) isiksuseks, kes on: õppiv, oskav, teadev, mängiv ja loov; suhtlev ja rääkiv (väitlev, lugev, uskuv, veenev, käskiv, kuuletuv...); koostöötav (korraldav, koordineeriv, täitev...); mõtlev ja mõtestav (mäletav, teadev, kujutlev, arutlev, seletav, kirjeldav, kaa-

3 Põhivajadustest tulenevad põhilised huvid. Thomson näeb vastupidist suunda. Kahjuks ei mahu see huvitav küsimus käesolevasse arutlusse. 
lutlev, põhjendav, õigustav...); mõtestav ja väärtustav (head halvast eristav ja eelistav, looduslikku ilustav, loomingut paremaks mõtlev...); fantaseeriv ja kujutlev; ennast ja teisi, maailma ja fantaasiaid väärtustav ja hindav, uuriv ja uudistav; sündmusi ettenägev ja ennetav; otsustav ja püüdlev; tundev ja kaasaelav (vaimustuv, rõõmustav, vihastuv, kurvastav, nautiv...) jne, (3) kes tegevuses ning keha, hinge ja vaimu muutustes läbib elukaare sünnist surmani.

Esitatud määratlus pole mõistagi ammendav. Näiteks, viiduna A. Schopenhaueri inimsaatuse põhimäärangu kolmikusse - mis keegi on, mida keegi omab, mida keegi kujutab (Schopenhauer 1994, 7 jj) — kuuluks see ilmselt esimesse määrangusse. Mis tegevusse puutub, siis ilmselt Schopenhaueri triaadi kaks ülejäänud määrangut on samuti taandatavad tegevustele. ${ }^{4}$

Inimese käsitlemisel tegutsemisloomuse alusel on vähemalt kaks tugevat külge. Esiteks, tegevuse väärtustamisel on kindel empiiriline põhi: tüüpilised tegevus- ja oskusmallid on tõigad sõltumata sellest, kuidas me neid hindame. Mõistagi võime eksida mõne tegevustüübi tuvastamisel, kuid see ei kummuta tüüptegevuste ja -oskuste olemasolu. Näiteks, läbi inimkonna ajaloo on selgelt vaadeldavad kasulike asjade (hüvede) vahetamise ja äravõtmise tüüpilised tegevusmallid, mille sooritamise läbi inimesed, seisused ja kogukonnad on elatunud. Mitte ainult loov töö, vaid ka sõjasaagi hankimine nõuab oskusi ja tööjaotust. Asjade naturaalne vahetus, müük raha eest, tootmine palgatööga, samuti nagu asjade võtmine sõjasaagiks, kogumine maksudeks või tootmine orjatööga rajanevad teatavatel institutsionaliseeritud tegevusmallidel. Samas on ilmne, et väljavaade põllusaaki erinevate hüvede vastu vahetada motiveerib maaharijaid töötama, väljavaade saagist igal sügisel ilma jääda sunnib neid aga varem või hiljem maaharimisest loobuma. Järgnev tabel illustreerib inimtegevuse mallide olemuslikke funktsionaalseid väärtusi.

\begin{tabular}{r|l|l} 
Esemestatud suhe: & $\begin{array}{l}\text { asjade (otstarvete) } \\
\text { vahetamine }\end{array}$ & $\begin{array}{l}\text { asjade (otstarvete) } \\
\text { jõuga anastamine }\end{array}$ \\
\hline Suhte väärtus & sooritus ja tagajärg & sooritus ja tagajärg \\
(võimaliku kasu ja & ennustatav; & juhuslik ja ootamatu; \\
kahju suhtena): & kindlustunnet tekitav; & ebakindlust tekitav; \\
& vastastikune, koostöine; & ühepoolne, vaenulik; \\
& tootlik, lisaväärtust & mittetootlik, väärtust \\
& loov; & kahandav; \\
& loovust ja oskus- & loovust mõlemapoolselt \\
& teadmisi motiveeriv; & pärssiv; \\
& väärtusi siirdav, säilitav & väärtusi raiskav ja \\
& ja kaitsev; & hävitav.
\end{tabular}

${ }^{4}$ Juriidiliselt seisneb omand kolmes õigustuses, mida sageli esitatakse tegevusnimedena: (asja) valdamine, kasutamine ja käsutamine. 
Vahetustehingu oskus- ja otsustusskeemi sisu on keerulisem, kui esmapilgul näib. ${ }^{5}$ Siin märkigem ära põhiline nõue: vahetus eeldab asjaosaliste isikute selget arusaamist, et nemad ega kolmandad isikud ei esita hiljem nõudmisi vahetatud asjadele. Otstarbekate asjade vahetus evib potentsiaali toota lisaväärtust: kui ühel inimesel on otstarbega asi, mida ta ei vaja, ja teisel on erineva otstarbega asi, mida tema ei vaja, kuid kumbki vajab teisel olevat asja (otstarvet), siis vahetamisel asjade kasutusväärtus suureneb, ilma et asjade juures midagi muutuks. ${ }^{6}$

Seega, mõned tegevusmallid on kahjulikud olemuslikult (nt röövimine), mõned normtaset rikkuvatena (nt ülemäärane maksukoorem); mõned on kasulikud olemuslikult (nt kunstilooming), mõned funktsionaalselt (nt seadusloome).

Inimeste käitumist ja inimühenduste ühiseluviise juhivad ja piiravad teatavad "normtasemed". Need on objektiivsed, meie hinnangutest sõltumatu suurusega tegurid, mis mõjutavad inimtegevust sellisel reeglipärasel viisil, mida võime nimetada normtasemeseadusteks. ${ }^{7}$ Näiteks, organismi tervisliku (kahjustamatu) toitumuse normtase määrab üksikisiku toiduvajaduse; sellest tuletatakse keerulisemad seaduspärasused, mille muutujateks on elutingimused, inimeste hulk ja ajaintervall. Erinevalt nomoloogilistest loodusseadustest on kõneksolevad seadused eksimuses või teadlikult teatava pingutusega eiratavad: näiteks võib inimene vajaduse sunnile vaatamata valida surma näljastreigi läbi. Seda moodust nimetatakse "praktiliseks paratamatuseks". ${ }^{8}$ Ehkki inimene suudab kannatada janu või nälga, ei kummuta see suutlikkus üldist, igal ajastul igat inimest sundivat vältimatut nõuet juua ja sü̈̈a selleks, et elada. Kasinate võimaluste korral väljendub see tugevaima nõudena püsida elus, rahuldatud esmavajaduste korral katab seda nõrgem nõue saada söögist ja joogist naudingut. Üldine normatiivne väärtusteskaala on tuletatav empiirilisel alusel, inimese kui meelelise ja mõtestava olendi kogemusest:

(1) hüvede ja mugavuste nautimine on meeldiv, puuduste ja ebamugavuste kannatamine on ebameeldiv;

(2) hüvede nautimise parim seisund on õnnelikult elamine, puuduste kannatamise halvim seisund on suremine kannatuste läbi.

5 (Rosentau 2004, 134-139).

${ }^{6}$ Otstarbe kui operatsionaalse funktsiooni mõiste kohta vt (Rosentau 2006).

7 Nn normtasemeseadustest (ingl 'normic laws') loodusseaduste süsteemis vt (Schurz 2001). "Normtasemeseadused on isereguleeruvate süsteemide fenomenoloogilised seadused", mis käsitavad nende süsteemide prototüübilisi normaalseisundeid mittestatistiliste mõõdetavate seisunditasemetena (Schurz 2001, 7 ja passim).

${ }^{8}$ (Thomson 1987, 4-6). 
Ehkki näib, et esimene tingimus on tundlik väärtushinnangute suhtes, ei kummuta skaalat ka kõige askeetlikum eluhoiak: teine tingimus nõuab äärmuslikumalegi askeedile vähemalt seda õnne, et oleks välditud tema surm kannatuste läbi. (Sestap pole vaja esimest tingimust karmistada ceteris paribus või summa summarum piirangutega.)

\section{Vajaduse mõiste tarvilikud tingimused}

Erinevaid teooriaid võrreldes ${ }^{9}$ leidsin, et vajaduse parim tähendusanalüüs lähtub kahju mõistest. See on organismi või isiksuse kahjustus, mida tingib teatava toime puudus. ${ }^{10}$ Nimetagem kahjustumist vältivaid toimeid vajadushüvedeks. Vajadushüve on tarvilik inimlike atribuutide saavutamiseks või säilitamiseks, selle puudus või kaotus (deprivatsioon) kahjustab isiku inimlikku elu või loomust. Vajaduse rahuldamine on paratamatu praktiliselt: inimesel on tahtevabadus end surnuks näljutada, kuid normaaltingimustel ei ole see mõistlik, sest hävitab kõige muu inimliku.

Vajaduse mõiste põhiterminite tarvilikkuse ja küllaldavuse analüüs siia ei mahu. Järgnevalt loetletud tingimused võivad moodustada bikonditsionaali üksnes "normaaltingimustel". Aga kas sotsiaalsed "normaaltingimused" pole mitte normatiivsed ega tingi ka vajaduste hinnangulisust? Oletan, et normtasemeseadustes leiab aset ettekirjutuste ja tõdemuste süntees, mis on teine teema, kuid selle sünteesi tõttu vajaduse mõiste ei ole (puhtalt) normatiivne.

Vajaduse mõiste tarvilikud tunnused on järgmised.

1) Vajaduse subjekt: inimene (isik) või inimeste ühendus (grupp, kogukond). Senised teooriad käsitavad vajaduste subjektina pigem indiviidi. Ent on alust arvata, et ka indiviididele taandamatute ühiste subjektide ühised vajadused on olemas: kiirabi, veevärk, tuletõrje jt linnaelu atribuudid on selliste paradigmaks.

2) Vajaduse objekt ehk vajadushüve: mingi asja või protsessi toime, mis rahuldab kindlat vajadust ja kõrvaldab vajaduspinge. Tavakeeles peame me vajaduse objekti all silmas kõnesoleva toime tekitajat (eset, ainet, seadet, tegu jne) ning enamasti on selline kõneviis õigustatud. Kuid rangelt võttes on vajaduse objektiks mingi funktsioonide ansambel, mis toodab rahuldatud vajaduse seisundeid. Vajadushüved ei ole ühetaolised. Näiteks, orgaanilised funktsioonid on bioloogilise liigi omadused, mis antakse edasi liigilt indiviidile pärilikul teel; koordineeritud koostöö funktsioonid on rajatud koostöös ja antakse edasi õpetuses; isegi indiviidide erivajadused on reeglina tingitud

9 (Thomson 1987), (Wiggins 1991), (Doyal ja Gough 1991) ning (Parve 2006) alusel.

${ }^{10}$ Määrav on just toime, mitte asi: mõelgem nt erinevatele samatoimelistele ravimitele, rikkis seadmetele jmt-le. 
koostöise eluviisi tulemustest: maohaavadega inimese ravivajadusest saab rääkida ainult seetõttu, et on olemas jagatud teadmine haavandtõvest, selle diagnoosist, ravist ja profülaktikast. Küsimus teatavate toimevahendite saadavusest muutub küsimuseks vajaduste olemasolust: vajadus insuliini järele tekib siis, kui insuliini toime on avastatud ja tootmisviis leiutatud. Lõpuks, vajaduse objektid on hüved, sest on kahju vältimisega saavutatava esmase heaolu tingimusteks.

3) Vajadushüve puudumisel vältimatult tekkiv kahju, mis rahuldatud vajaduse suhtes tähendab potentsiaalset kahju. Tegemist on kontrafaktuaalse seosega vajadushüve puuduse ja sellest tingitud kahju vahel: kui tarvilikud toimeefektid puuduvad (mis anormaalsena on käsitatav kontrafaktina), siis käivituvad vältimatud "taandeprotsessid", mis põhjustavad subjektile kahju - suurenevast vajaduspingest ja kestvast kannatusest kuni tervise või elu kaotuseni. Potentsiaalne "vajaduskahju" on ettenähtav: loomi juhivad potentsiaalide maailmas refleksid ja instinktid, arukaid olendeid lisaks ettekujutused (vajadustest, nende rahuldamise võimalustest, rahuldamatuse tagajärgedest jne.)

4) Vajaduse vältimatuse tingimused on sõltuvusseosed, mis valitsevad inimese keha ja vaimu ning tema materiaalse ja kultuurilise elukeskkonna vahel. Seosed käsitavad ainevahetust, liikuvust, suhtlust, õppimist, tarbimist, motivatsiooni, enesemääramist, koostööd, jätkusuutlikkust jne. Seosed on seletatavad nomoloogiliste loodusseaduste ja humanoloogiliste normtasemeseaduste alusel. Seadused on objektiivsed, ent siiski mõistuse konstrueeritud.

5) Vajaduse pingetegur on eelnimetatud sõltuvusseostest tulenev sund tegutseda vajaduse rahuldamise sihil. Sunni ilminguteks on muuhulgas impulsid, ajendid, motiivid, otsustused. Vajadus on tegutsemise objektiivne motivaator, mille vektoriks on potentsiaalse kahju vältimine.

Vajadusi määratlev täielik liigitus näib võimalik ainult põhiterminite variatsioonide alusel.

\section{Vajaduste tüübid}

Kirjaruumi nappusel illustreerin vajaduste tüüpe mitteformaalsete näidetega, esitamata olemasolevat formaalset analüüsi. ${ }^{11}$ Inimvajadused on liigitatavad vahetuteks ja vahendlikeks. ${ }^{12}$ Järgnevas liigituses on esimesed kaks vahetute vajaduste tüübid.

1) Organismi füsioloogilised vajadused

${ }^{11}$ Selline leidub autori raamatukäsikirjas Inimvajadused. Humanoloogilised normtasemeseadused.

${ }^{12}$ Samas võtmes saab rääkida ka otsestest ja kaudsetest või esmastest ja tuletatud vajadustest. 
Vee, hapniku ja toitainete vajaduste määratlemisel pole erilisi probleeme: need on nomoloogiliselt paratamatud ja ajalooliselt püsivad. Orgaanilised põhivajadused on määratud bioloogilist liiki kehastava organismi ainevahetuse struktuuri ja funktsioonidega.

Vesi on inimesele (tingimata) vajalik, sest vee toime-efektid on organismi ehituse ja ainevahetuse tarvilik tingimus ning tõrgeteta ainevahetus on inimese tervisliku elu tingimus teiste elutingimuste rahuldatuse korral, nii et vee puudus ja sellest tingitud ainevahetuse häired tekitavad vältimatult inimesele tõsist kahju: kui inimene ei saavuta vee toime-efekte, siis ta kannatab janu, kuni sureb.

Füsioloogilised vajadused on esmased ja tingimatud ning objektide toime organismis vahetu. Isendi erivajadused on määratud tema organismi iseärasustega: näiteks suhkruhaigus tingib toitumise ja ravi erivajadusi. Erivajadused on siiski üldised kontrafaktuaalses mõttes: iga inimene, kes satuks vaadeldavatesse tingimustesse, omaks neist tingitud erivajadusi.

2) Organismi ja isiksuse elutingimusvajadused

Teatavad elulaadi muutused tingivad pöördumatuid kohastumusi: näiteks ehitiste, rõivaste ja tule kasutuselevõtt kehasoojuse säilitamiseks võimaldas asuda elama külmematele aladele. Sealsetes elutingimustes on tuli, rõivad ja peavari põhilisteks vajadushüvedeks, milleta inimesed vältimatult kannataksid kahju.

Eluase on inimesele tingimata vajalik kehasoojuse säilitamiseks piirkondades, kus jahe või niiske õhk, või tuul või vihm jahutavad inimese keha alla normaaltemperatuuri (nomoloogiline normtasemeseadus), nii et ilma eluasemeta kannatab ta külma või haigestub või külmub surnuks.

Erinevalt orgaanilistest ei ole põhilised elutingimusvajadused algsed, vaid on ajalooliselt tekkinud. Need on määratud populatsioonide ja isendite olelemistingimuste ja eluviiside põhjalikest muutustest, mis omakorda on muutnud inimese orgaaniliste põhivajaduste rahuldamise tingimusi ning "kasvatanud" uut tüüpi põhivajadusi. Mingi vajaduse ajalooline teke ei tähenda aga, et see oleks mis tahes hetkel tahteliselt "tagasipööratav".

Esmaste elutingimusvajaduste head tüüpnäited on keel ja tööjaotusega koostöö. Inimhulkade oskuslik, koordineeritud tööjaotusega koostöö on fundamentaalne sünergeetiline vahend nii ühiste ja üldiste kui ka üksikute isiklike eesmärkide saavutamiseks. Koostöö loob põhja suuremale osale inimlikele tegevustele ja väärtustele. Koostöös on rajatud uusi elamise viise ja elukeskkondi. Tähelepanuvär̈seim ja suurimat hulka inimesi puudutav on mõistagi linn. Linnas koonduvad kõik vajaduste tüübid. Linn on eluviis, keskkond, sootsium, "atraktor" ja "mahuti": linnadeta ei suudaks Maa praegust elanikkonda ära majutada! Linn kehastab suurt hulka normtasemeid majanduslikke, energeetilisi, kultuurilisi, hügieenilisi, julgeolekulisi jne —, 
mille eiramine kellelegi kahju tekitamata pole mõeldav.

Leiutanud keele ning avastanud võime sõnumites mõtteid vahetada, on inimene omandanud vahendi kavatsuste kooskõlastamiseks ja tegevuse koordineerimiseks. Ennekõike võimaldas see tõhusat elatusvahendite koostootmist. Ühelgi teisel Maa elusolendil ei ole sõnalist mõttevahetust; võib-olla on keel üldse ainus mõttevahetuse viis. Koostööd ja õpetamist võimaldav keel on muutnud inimeste eluviisi sedavõrd, et keeleoskus on vajadus ja oskamatus tähendaks kahju ja kannatusi. Keele vajadus on nii põhiline ja mitmekihiline ning keel nii paljude funktsioonidega, et siin ei ole võimalik seda lähemalt kirjeldada.

Elutingimusvajadusi saab liigitada (või loetleda) empiirilise sisu alusel: ilmastiku, ressursside, tootmise, tehnoloogiliste jne tasemete, samuti majanduslike, poliitiliste, kultuuriliste, religioossete, psühholoogiliste jm tõuke- ja tõmbejõudude alusel.

Kirjeldatud kaks tüüpi vajadusi on vahetud ja tingimatud. Mitmed teooriad piiravad vajaduse mõiste just nii range tähenduse ja kitsa mahuga. Sellel on mõningaid eeliseid: vajadus on ilmne ja selgelt tuvastatav, sellel on ajas ja ruumis vähem varieeruvaid ja rohkem püsivaid tingimusi. Paraku tingib vajaduse mõiste piiramine orgaaniliste ja esmavajadustega soovimatu "vajaduste diktatuuri”: kui saab tagatud täis kõht, töö värskes õhus, läbikäimine ja tervis, võiks inimene järelikult ühtviisi väärikalt elada nii enda talus, kolhoosis kui ka töölaagris. Sestap tuleb vajaduse mõistet laiendada nii, et see hõlmaks ka teatavaid eluviisi ja elatustaseme tingimusi. Need aga on tekitatavad kindlate vahenditega. Vahendlikud vajadused on tuletatavad vahetutest esmavajadustest kombinatsioonis elamise sattumuslike, ent praktiliselt paratamatute tingimustega.

Vahendlikeks vajadushüvedeks on:

a) vahetute vajadushüvede allikad;

b) vajadushüvede loomise või tootmise vahendid;

c) sattumusliku kahju vältimise, kõrvaldamise ja vähendamise vahendid;

d) eluviisi normtasemete säilitamise vahendid.

Need on arengulooliselt tingitud, ahelpõhjuslikud ja vahendlikud: kindla otstarbe (vahendi) rakendamine annab tulemuse, mis rahuldab mõnd põhivajadust. Vajadusahel võib olla pikk: mõelgem nt leiva tootmisele ja turustamisele. Ahela "vedavas" otsas on esmased vahetud vajadused, "veetavas" otsas ressursid ja tegevused, mis viivad esmavajaduste rahuldamiseni. Aga tähelepanu: vahendlikud vajadused ei ole taandatavad vahetutele vajadustele! Sest inimese isiklikud ja koostöised leiutamise ja avastamise võimed, 
oskused ja meetodid, tema loovus ja tootlikkus, mille kaudu vajaduste keerukaid ahelaid rahuldatakse - ja üha rajatakse - , ei kuulu esmavajaduste tingimuste hulka.

Kasutatavad vahendid pole mõistagi üksnes materiaalsed. Lisaks leiduvad abstraktsed ja virtuaalsed vahendid. Näiteks õigusnormid on vahendid, millel on muuhulgas isesoorituvaid abstraktseid funktsioone. ${ }^{13}$ Oskused on virtuaalsed omadused: need ilmnevad üksnes tegevuses, ent eksisteerivad ka siis, kui neid ei kasutata.

Niisiis, vajaduste tüpoloogia jätkub vahendlike vajadustega.

3) Põhilised vahendivajadused tõsise sattumusliku kahju vältimiseks või vähendamiseks

Võtkem tüüpobjektiks ravimid ja ravioskused. Ravivahendite vaatlus näitab ilmseimal viisil oskuste kuulumist vahendlike vajadushüvede hulka. Erinevalt vahetutest vajadustest kuulub vahendlike vajaduste loogiliste eelduste hulka hulk empiirilisi tingimusi otstarbekate vahendite tegeliku olemasolu ja küllaldase saadavuse kohta. Veevajaduse eelduste hulka ei kuulu vee saadavus, kuid mingi ravimi vajaduse tingimuseks on selle ravimi olemasolu ja saadavus. Vajadushüveks ei saa olla väljamõeldud olematu asi (otstarve) ega ka olemasolev asi (otstarve), kui keegi ei oska seda kasutada. Ent üks oluline mööndus tuleb teha: võimalikud on n-ö kaugemad tuletatud vajadused. Näiteks, kui on olemas idee ravivahendist, millega on võimalik säästa inimeste elu ja tervist, siis võib juba esineda vajadus arendada ideest ravivahend. Milles seisneb sellise vajaduse sund - ravivahendit ei leiutata reeglina ju enda jaoks? Ilmselt on tegemist ühiselt jagatava, nii egoistliku kui ka altruistliku murega inimeste hea elukäigu pärast, mille tähtsaima joonena nähakse tõsiste kahjustuste puudumist.

4) Tuletatud vahendi- ehk otstarbevajadused

Otstarbevajadused käsitavad vajadushüvede saavutamise vahendeid.

Põhilised vahendivajadused on tingitud füsioloogilistest, elutingimuslikest ja kahjuvältimise vajadustest ning rajanevad loova ja leidliku inimese innovaatilistele saavutustele. Viimased tingivad indiviidide ja kogukondade eluviisi muutusi. Näiteks tule "taltsutamine" muutis toitumist, majutumist ja tootmist sel määral, et tulest sai põhiline ja vältimatu vajadushüve. Kui inimesed tänu tulesoojale rändasid külmematele aladele, sattusid nad (pöördumatult) eluoludesse, milles tuli oli kahjustumise ärahoidmiseks vältimatu: tuleta oleks inimene kannatanud ja hukkunud. ${ }^{14}$ Ajapikku muutus tuli põ-

${ }^{13}$ (Vt Rosentau 2004, 249-250, 253-254).

${ }^{14}$ Wiggins teeb vahet orgaanilistel põhivajadustel ja põhjalikel elulaadist tingitud vajadustel, Thomson näib et mitte. Wiggins nimetab viimaseid sügavalt juurdunud vajadusteks (Wiggins 1991, 20). Samuti näib Wiggins möönvat põhivajaduste mõningat eiratavust ja vajaduste objektide asendatavust üldises ja pikas perspektiivis, Thomsoni käsitlus ei paindu 
hiliseks energiaallikaks ja tulest sai ühiskonna põhihüve. Enamik transpordivahendeid liigub siiani tulejõul. (Tuli täidab ka naudingu otstarvet, kuid see ei ole vajadus tõsises mõttes.)

Tuli on inimesele vajalik liha küpsetamiseks tingimustes, kus liha(loomad) on toitainete põhiline allikas, sest tule kuumus on liha küpsetamise tarvilik tingimus eluviisis, kus puuduvad teised soojusallikad, ja küpsetatud liha on inimese tervisliku toitumise tingimus teiste tervisliku elu tingimuste rahuldatuse korral, nii et tule ja küpsetatud liha puudumine tekitab inimesele vältimatult tõsist kahju: kui inimene ei saa tulega liha küpsetada või ei leia muid toiduvalmistamise viise või toitainete allikaid, siis ei saa ta antud eluviisi tingimustes tervislikult toituda.

Üldiselt on otstarbevajadused määratud innovaatiliste, sealhulgas tehniliste, metodoloogiliste, organisatsiooniliste jm lahenduste otstarvetest.

5) Põhilised koostöövajadused

Inimeste ühiselu iseloomustavad teatavad normtasemed. Näiteks, muistsed kütid-korilased, kes pidid rändama toidu järele, ei saanud lubada rohkem kui ühte-kahte imikut ema kohta. Ent kui inimesed võtsid omaks põlluharimiskultuuri ja sellega paikse eluviisi, kadus laste arvu "liikumispiirang" ja asendus toitumispiiranguga: lapsi saab olla nii palju, kui palju suudetakse ära toita. ${ }^{15}$ Viimane norm ei astu aga jõusse kohe, sigitamise ja sünnitamise protsessis, vaid alles siis, kui lapsed kasvavad välja imikueast. Kuivõrd laste nälgimine on tõsine kahjustus, sünnitas kogukonna kasv vajaduse toota rohkem toitu. Toiduainete tootmine nõuab pea alati koostööd, vähimal juhul pere piires, enamasti aga kogukonna või ühiskonna tasemel. Koostööd laias tähenduses: nt kaubavahetus ja raha on ulatusliku iseregulatiivse koostöö viisid ja vormid.

Kaubandus on (tuletatult) vajalik, sest esmased vajadushüved jaotuvad ajas ja ruumis ebaühtlaselt ning ei ole igale vajajale kättesaadavad; vajadushüvesid tuleb jaotada nii, et see motiveeriks (taas)tootmist; kaubavahetuse puudumine tingiks vajadushüvede puuduse ja inimestele vältimatut tõsist kahju.

Teatavasse arenguspiraali sisenedes "mässib" ühiskond end üha tihedamalt kindlatesse normtasemetesse. Ainsaks valikuks jääb neist tingitud vajaduste rahuldamine või kahju kannatamine. Tõeliselt vajalik koostöö koondub põhivajaduste rahuldamisele. See ei tähenda, et muu koostöö, näiteks "puhtalt loominguline" ei oleks väärtuslik. Kuid varem või hiljem viib ka kultuurikoostöö selliste normtasemete tekkeni, mille isiklik saavutamatus on isikut kahjustav.

Normtasemed pole siiski absoluutsed. Mõnedest on võimalik vabaneda. Näiteks on mõeldav (Polüneesias ka kinnitust leidnud), et väljaränna-

aga selleski küsimuses.

15 (Vt Diamond 2002, 89). 
nud maaharijad võivad naasta küttimise-koriluse juurde. Kuid tavaliselt, sõltuvalt konkreetsetest asjaoludest, taandekohanemine pigem kahjustab inimest. Sestap esineb tavaliselt vajadus säilitada olemasolev eluviis ühes selle normtasemete ja koostöövormidega. Ent globaalselt pole seegi jääv: oht rikkuda Maa elukeskkond seab Õhtumaise eluviisi levikule piirid ja tõsise nõude selle kiireks muutmiseks.

6) Põhilised allikavajadused

Enamik vajadushüvesid ei jaotu Maal ühtlaselt ega ole kõigile ühtemoodi kättesaadavad. Sestap on kogukonnad alati olnud sõltuvad allikatest: veekogudest, metsadest, kõlvikutest, maardlatest jne. Kuna allikasõltuvus mõjutab pea kõiki teisi vajadusetüüpe, siis on mõttekas käsitada neid eraldi vajadusetüübina.

Veeallikas on inimesele tingimusteta vajalik, sest vesi on inimese elamise bioloogiline tingimus ning vesi ei ole alati ja kõikjal kättesaadav; veeallika puudumine tähendab vee puudust ja vältimatut tõsist kahju: kui inimene ei saavuta veeallikat, siis ta kannatab janu või sureb.

Vahendi-, koostöö- või allikavajaduste tõsiduse aste sõltub selle esmavajaduse tõsidusest, mille rahuldamiseks vahendit, koostööd või allikat kasutatakse. Sestap ei kajasta ülaltoodud järjestus nende tõsiduse astet.

7) Eluviisi normtasemevajadused

Eluviisivajadused on eelmistega võrreldes madalaima tõsidusastme, nõrgima vajaduspinge ja vähima nõudlikkusega teokavatsuste suhtes. Nende rahuldamine toimub läbi väärika elu, osaluse ja eneseteostuse. "Pindmiste" normtasemete keerukuse tõttu on tegemist vajaduste keerukaima tüübiga. Seepärast jätkem täpsem määratlemine tulevaseks ülesandeks. Näib, et eluviisivajadustel on hulk alatüüpe. Ent ka probleemid on ilmsed. Kas eluviisi normtasemed on üldinimlikud või määratud ühiskondliku seisundiga? Kas normtase peab olema üldiselt tunnustatud või piisab empiirilisest tõigast, et arvestatav hulk inimesi elab sellel tasemel? Kas eluviisi normtaseme määrab elitaarne või massikultuur? Või miski muu? Kas normtasemed on tingimata samaaegsed (sünkroonsed) või saavad olla ka "ette- või tagasivaatavad", nii et mineviku või tuleviku tasemed võiksid olla määratud hilisemate või varasemate väärtuste alusel?

Võimalik, et mõned vajadused on määratud pindmiste elustandardi nõuetega. Sellisel juhul on olemas ka nö etalon-vajadused. Näiteks, mõned hügieeninõuded on küllalt tõsise tähendusega suhtlemisele, ent mitte tervisele. Etalonhüvedest ilmaolemise kahjuriske on keeruline tuvastada ja hinnata. Kas maal elav inimene kannatab tõsist kahju, kui ta ei pääse osalema linna kultuurielus? Kas reklaamilause "kuidas ma enne ilma selleta küll hakkama sain!?” võib osutada vajadusele? Ehk kas innovaatilised lahendused võivad "elustandardit" muuta nii oluliselt ja kiiresti, et lahenduste efektidest ilma- 
jäämine tähendaks isiku tõsist kahjustumist? Kahju võib väljenduda isikuomaduste saavutamatusena (kui "normaalsed asjad" pole isikule üldse kättesaadavad) või taandekohanemise vaevadena (kui isik minetab varasema juurdepääsu neile).

Tegutseva inimese põhiatribuudiks on oskused. Oskused on olulised vajaduse mõiste suhtes vähemalt kahest aspektist. Inimene kannatab kahju, kui (1) ta on eluressursse kulutades omandanud oskused (eriala), aga ei saa neid kasutada; (2) ta on võimeline omandama eriala, aga ei saa seda teha temast olenematute piirangute tõttu.

Lõpuks kaks kõnekeelset "vajadusetüüpi", mis ranges tähenduses ei ole vajadused, vaid vajaduse-sarnased mitte-vajadused. 'Vajaduse' tavakasutus sensu largo on ilmne tõsiasi. Mis paraku eksitab tõeliste vajaduste määratlust ja tuvastust.

Kvaasivajadused. Leidub hulk eluviisist tingitud motivaatoreid, millest räägitakse nagu vajadustest. Näiteks räägitakse "vajaduste tekitamisest" sageli meedia- ja reklaamiõpetustes. Reklaamiga ei tekitata vajadusi, vaid soove, impulsse vm. Tõsi, "tarbimissooviga" võib läbi eeskujude ja saavutusmotiivi kaasneda tugev sund isikule, ja kui soov rahuldamata jääb, võib ta frustratsiooni läbi hingeliselt kannatada. Mõelgem "keskmise" pere poes nutvale lapsele, kes ei saa seda, mida ta just tahab - kas ta isiksus saab kahjustatud!? Teatava lühiajalise kannatuseriski tõttu räägimegi justnagu-vajadustest, eristamaks neid kahjututest valevajadustest. Kumbagi eristab tõelistest vajadustest mittevastavus mitmele ülalesitatud vajaduse tarvilikule tingimusele.

Omandatud sõltuvused on kvaasivajadused kõigil juhtumitel, kui nende teke on välditav. Piltlikult: alkohoolik ei vaja viina, vaid viinaravi. Analüüs jäägu siin lugeja teha.

Pseudo- ehk valevajadus on reaalsele või kujuteldavale objektile suunatud hoiak (meeldivus, soov, iha), mida tavatsetakse tähistada vajadusena, ent mille rahuldamatus ei tekita isikule tõsist kahju. Tõsi, tõeliste ja valevajaduste suhtes tuleb lahendada kaks seotud probleemi: (a) isikul kord olnud sooviobjekti minetamine tundub oluliselt halvem seisundist, kus isikul pole seda objekti kunagi olnudki; (b) kahju juriidiline mõiste ei tee vahet vajaduse ja soovi objektidel. Vastus esimesele leidub vajaduse mõistes: vajadushüve puudusest tingitud kahju on kontrafaktuaalne ja praktiliselt paratamatu, soovi rahuldamatuse või sooviobjekti minetamise kahju ei ole praktiliselt paratamatu, vaid on sattumuslik tõsiasi. Vastus teisele probleemile on õigusteoreetiline, mis siia ei mahu, kuid väärib käitlemist.

Käesoleva mudeliga on sidus aga tõdemus, et eilne luksus võib täna olla vajadushüve.

Vahel räägitakse instrumentaalsetest vajadustest. Mõned uurijad käsita- 
vad kõiki vajadusi instrumentaalsetena (vt Thomson $1987,2,7){ }^{16}$ Üldine skeem on selline: ' $p$ on tarvilik selleks, et (teha, saavutada) $q$ ' - 'Selleks, et masin liiguks, on vaja mootorit'. Selline seos võib olla tõelise vahendivajaduse tingimuseks, kui esinevad ka muud tarvilikud tingimused. Seega tuleb eristada: (1) vahendivajadusi esmavajadusi rahuldavate otstarvete järele; (2.1) instrumentaalseid eesmärgiseoseid; ${ }^{17} \mathrm{ja} \mathrm{(2.2)}$ instrumentaalseid otstarbeseoseid. ${ }^{18}$ Kahe viimase kooslusi ongi nimetatud 'instrumentaalseteks vajadusteks'. Ent need ei ole vajadused.

Sõna 'vajadus' ('vajama') kõnekeelset kasutust ei tarvitse esitatud mudeli alusel üle arvustada, "reformimisest" rääkimata. Kuid teatavate otsuste tegemiseks on vajaduse range tähenduse mõistmine vajalik.

Kokkuvôtvalt: inimese vajadus väljendab üldistatult mingit elutähtsat tingimust, mille tegelik puudus teatava aja jooksul vältimatult tekitab talle tõsist kahju ning mille potentsiaalne puudus või lühiajaline puudus avaldab inimesele praktiliselt paratamatut motiveerivat survet. Vajadus on sünteetiline mudelmõiste, millel on nii seletav (teoreetiline) kui ka õigustav (praktiline) funktsioon. Mis tahes tüüpi vajaduse rahuldamise tõeliseks aluseks on isiksuse tõsise kahjustumise vältimine.

\section{Kirjandus}

Diamond, J. (2002). Püssid, pisikud ja teras. Inimühiskondade erinevad saatused, Eesti Entsüklopeediakirjastus.

Doyal, L. ja Gough, I. (1991). A Theory of Human Need, The Macmillan Press Ltd.

Maslow, A. H. (1987). Motivations and Personality, 3. tr, Addison-Wesley Longman.

Parve, V. (2006). Vajaduse analüütikalt vajaduspraktikasse, Studia Philosophica V (41): 95-111.

Rosentau, M. (2004). Õiguse olemus: sotsiaalse käitumise funktsionaalne programm, doktoritöö, Tartu Ülikool.

${ }^{16}$ Teisal on käsitletud neid eesmärkvajadustena (vt Parve 2006, 98, 100).

${ }^{17} \mathrm{Nt}$ (Parve 2006, 104) nimetab taolist seost 'teleoloogiliseks' ehk 'vajaduseks kui eesmärgiks': 'P tahab süüa, selleks et suuta töötada'; 'P vajab puusaproteesi, selleks et suuta käia' jne. Teisal nimetab Parve seda seost 'vitaaleesmärgiks', mis vajadusega samastamata oleks oluliselt täpsem määrang (Parve 2006, 106).

${ }^{18}$ (Vt Rosentau 2006, 124-126). 
Rosentau, M. (2006). Otstarbeanalüüsist, Studia Philosophica V (41): 117133.

Schopenhauer, A. (1994). Elutarkus, Kupar, Tallinn.

Schurz, G. (2001). What is 'normal'? An evolution-theoretic foundation of normic laws and their relation to statistical normality., Philosophical Prepublication Series at the University of Erfurt 4.

URL: http://www.blutner.de/Logica/Texte/Schurz_Normal.pdf

Thomson, G. (1987). Needs, Routledge \& Kegan Paul, London \& New York.

Wiggins, D. (1991). Needs, Values, Truth. Essays in the Philosophy of value, Vol. 6 of Aristotelian Society Series, 2. tr, Blackwell, Oxford \& Cambridge.

\title{
What does the human really need? A typological definition
}

\begin{abstract}
Human need is an empirical-theoretical concept allowing formulation of humanological normic-level laws. The author proposes a theoretical model, which is able to describe a certain set of practically necessary phenomena of human life, to explain the appearance of these phenomena, and to justify decisions aiming at needsatisfaction, i.e. avoidance of serious harm. The necessary conditions of the model are a subject of the need (personal or collective), an object of the need (an appropriate operational function (purpose)), the potential harm of an unsatisfied need, nomological and humanological conditions of unavoidability of need, and the tension-factors of the need. There are two categories and several types of human needs. The immediate needs are the physiological and psychological functionality of an organism and the immediate life-conditions of an organism and personality. The intermediate, i.e. functional and circumstantial, needs are for the innovative means of direct harm avoidance and remedy, for the innovative means of the basic need-satisfaction, for the cooperation and for the sources (resources) of the basic need-satisfaction, and for the innovative providers of normal (normic-level) life-conditions. Therefore, the need is a vitally important condition, ongoing shortage of which inevitably and seriously harms a person, but a potential or a short-term shortage of which motivates him or her to practically necessary action. The genuine ground of need-satisfaction is the avoidance of causing serious harm to the human personality.
\end{abstract}

Keywords: human nature, human activity, human needs, need-satisfaction, lifestyle, normal life-conditions, humanological normic-level laws 